\title{
RUSSIAN FOREIGN TRADE IN APRIL 2015
}

\author{
N.Volovik
}

In Q1 2015, merchandise foreign trade volume fell sharply in G7 and BRICS economies. Russia's exports and imports volumes fell to the bottom low since Q1 2009. Russian foreign trade turnover declined in January-April 2015 against the same period 2014 practically with all countries except Cuba. The number of restrictive measures applied to the commodities imported from the EAEU is growing.

Against a backdrop of an appreciating US dollar and declining oil prices, total merchandise trade indices fell sharply in Q1 2015: according to OECD ${ }^{1}$ quarterly report, the volume of imports to G7 and BRICS economies fell by $9.5 \%$ and exports-by $7.1 \%$ against Q4 2014.

In the United States exports and imports were affected by a labor dispute at important West Coast ports ${ }^{2}$, declined by $7.1 \%$ and $4.2 \%$, respectively in Q1 2015. In Canada exports dropped by $10.9 \%$ and imports - by $7.9 \%$. Similar sharp falls took place in the United Kingdom with imports dropped by $9.5 \%$, and exports - by $12 \%$.

Exports and imports volumes reported a fall amongst large countries of the European Union. For example, in Germany exports fell by $8.6 \%$ and imports - by $8.2 \%$. In Italy - by $9.3 \%$ and $8.5 \%$, and in France - by $9.6 \%$ and $9.2 \%$, respectively.

In comparison with other developed economies, in Japan exports fell less markedly - by $4.5 \%$ but imports were down $9.8 \%$.

1 http://www.oecd.org/newsroom/international-trade-statistics-trends-in-first-quarter-2015.htm

2 Due to labor dispute between dockers and transport companies, 29 West Coast ports practically did not operate which caused record losses in the US trade with Asian countries.
Merchandise trade also contracted in BRICS member states in Q1 2015. Indian foreign trade turnover sharnk by about $20 \%$ and reached its lowest levels since 2008 financial crisis. China registered imports fall by $14.2 \%$ and exports by $2.7 \%$. In South Africa export volumes contracted by $7.1 \%$ and import - by $4 \%$.

In Russia a combination of factors, including EU sanctions which compounded the effects of lower crude prices and the depreciation of the ruble saw exports and imports shrink to their lowest levels since Q1 2009.

In April 2015, main indices of the Russian foreign trade continued declining. For instance, foreign trade turnover calculated on the basis of balance of payments methodology constituted $\$ 47.9 \mathrm{bn}$ which is below the index in April 2014 by $36.4 \%$. Merchandise exports constituted an amount of $\$ 31.5 \mathrm{bn}$ which is $33.9 \%$ less than the same index in 2014. In comparison with April 2014, imports contracted by $40.8 \%$ and came to $\$ 16.4 \mathrm{bn}$. Foreign trade balance was positive but fell by $24.5 \%$ down to $\$ 15 \mathrm{bn}$.

In April 2015, the world mineral resources market registered some revival. Bloomberg Commodity Index (BCOM) calculated by the agency along 22 commodities sold on the US commodity exchanges grew by $5.7 \%$ against March (from 98.12 to 103.75) which was

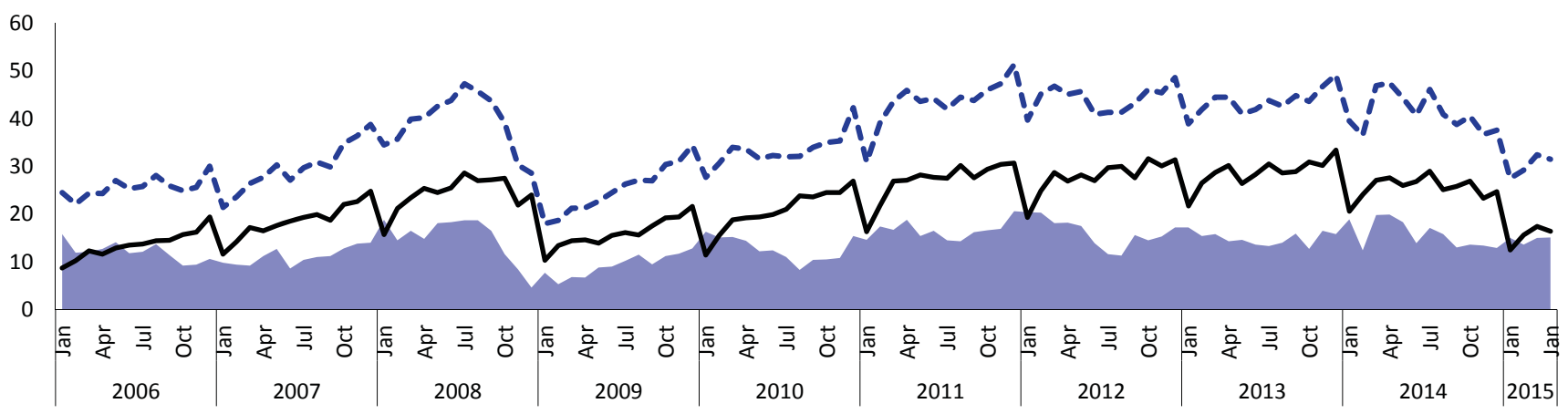

Balance $\quad-$ - Export Import

Source: the CBR.

Fig. 1. Main indices of Russian foreign trade (\$ bn) 
AVERAGE MONTHLY WORLD PRICES IN APRIL OF CORRESPONDING YEAR

\begin{tabular}{|l|c|c|c|c|c|c|c|c|c|c|c|c|}
\hline & 2004 & 2005 & 2006 & 2007 & 2008 & 2009 & 2010 & 2011 & 2012 & 2013 & 2014 & 2015 \\
\hline Brent, US\$/t & 33.5 & 50.6 & 68 & 68.32 & 108.26 & 50.85 & 84.98 & 123.07 & 120.46 & 102.9 & 104.8 & 59.39 \\
\hline $\begin{array}{l}\text { Natural gas3*, } \\
\text { US\$/thousand } \mathrm{m}^{3}\end{array}$ & 3.92 & 5.86 & 8.24 & 8.00 & 12.19 & 8.51 & 7.52 & 10.36 & 11.42 & 12.88 & 10.73 & 7.42 \\
\hline Copper, US\$/t & 2,950 & 3,395 & 6,370 & $7,766.5$ & $8,684.9$ & $4,406.6$ & $7,745.1$ & $9,483.3$ & $8,289.5$ & $7,234.3$ & $6,673.6$ & $6,042.1$ \\
\hline Aluminium, US\$/t & 1,734 & 1,894 & 2,620 & $2,814.8$ & $2,959.3$ & $1,420.9$ & $2,316.7$ & $2,662.6$ & $2,049.7$ & $1,861.7$ & $1,810.7$ & $1,819.2$ \\
\hline Nickel, US\$/T & 12,872 & 16,142 & 17,935 & 50,267 & 28,763 & 11,166 & 26,031 & 26,329 & $17,939.8$ & 15,673 & 17,373 & 12,831 \\
\hline
\end{tabular}

* European market, average contract price, franko border.

Source: World Bank.

the highest monthly growth since February 2014. The following considerations contributed to it:

- Investment in commodities in April turned out to be more profitable than investment in shares, bonds and the US dollars;

- Investment managers increased long positions on commodities part of Index by $\$ 11.8 \mathrm{bn}$;

- Crude price demonstrated robust monthly growth (Brent crude went up by $6.5 \%$ ) due to the fact the oil glut somewhat subsided;

- Copper by the month end posted the largest for 40 months appreciation due to projected stabilization of the Chinese economy which is the largest global consumer of industrial metals.

As a result, 14 commodity positions out of 22 listed in the Index in April were more expensive than in March.

In April 2015, average price of Urals crude was $\$ 59.16$ per barrel which is half the price registered in April 2014 (\$106.56 per barrel). In comparison with March 2015, ( $\$ 54.53$ per barrel) average price of Urals crude in April went up by $8.5 \%$. For 4 months 2015, average price of Urals crude shark on the same period of last year by half - to $\$ 54.3$ per barrel.

According to the data released by the Ministry of Economic Development of Russia, from 15 May through 14 June 2015, average price of Urals crude was $\$ 62.17$ per barrel or $\$ 453.8$ per ton. As a result, from 1 June 2015, export duty rate on crude will be $\$ 143.1$ per ton against \$144.4 per ton in June. Export duty rate on light oil products will constitute $\$ 68.6$ per ton, on black oil - \$108.7 per ton. Export duty on straight-run gasoline will constitute $\$ 121.6$ per ton, commercial petrol - $\$ 111.6$ per ton. Duty of diesel oil will be $\$ 68.6$ per ton. Export duty on liquefied hydrocarbon gas will remain at zero level.

According to the London Metal Exchange data, in April 2015 on previous month nickel wend down by $7.0 \%$, aluminium up 2.5\% and copper up 1.7\%. Against April 2014, price of aluminium went up by $0.5 \%$, price of copper shrank by $9.5 \%$ and of nickel down $26.1 \%$. In JanuaryApril 2015 against the same period 2014, price of copper down $15.2 \%$, nickel $-8.7 \%$ and aluminium up $4.1 \%$.
In April 2015, the FAO Food Price Index fell to its lowest level since June 2010 - 171 points down 2.1 points (1.2\%) from downgraded March index and down 40.5 points (19.2\%) from its level in April 2014. Downward trend on dairy products, cereals and vegetable oil was registered. At the same time, in April 2015, for the first time since August 2014 price of meat went up.

According to the data released by the Bank of Russia, in January-April 2015, Russia's foreign trade turnover constituted $\$ 182.4 \mathrm{bn}$ down $32.7 \%$ against JanuaryApril 2014, of which exports - \$120.5bn (down by $29.3 \%$ ), imports - $\$ 61.9$ bn (down by $38.3 \%$ ). Trade balance surplus declined to $\$ 58.7 \mathrm{bn}$ against $\$ 70.3 \mathrm{bn}$ in January-April 2014.

Declined of exports and imports in the first four months 2015 affected all extended merchandise nomenclature. ${ }^{1}$

Table 2

\section{EXPORTS AND IMPORTS INDICES DEVELOPMENT IN JANUARY-APRIL 2015 ACROSS MERCHANDISE SECTORS (IN \% TO JANUARY-APRIL 2014)}

\begin{tabular}{|l|c|c|}
\hline \multicolumn{1}{|c|}{ Merchandize sector } & Export & Import \\
\hline $\begin{array}{l}\text { Food products and agricultural } \\
\text { raw materials (except textile) }\end{array}$ & 84.7 & 60.1 \\
\hline Mineral products & 64.3 & 70.5 \\
\hline Fuel and energy products & 64.2 & 75.1 \\
\hline Chemical industry products, rubber & 89.8 & 71.8 \\
\hline rawhide, furs and articles & 76.2 & 65.7 \\
\hline made of them & 82.9 & 61.2 \\
\hline Timber and wood pulp products & 79.3 & 65.0 \\
\hline Textile, textile goods and footwear & 69.3 & 62.6 \\
\hline Precious stone, precious & 94.0 & 61.1 \\
\hline metals and their products & 104.8 & 58.1 \\
\hline Metals and their products & 107.4 & 61.8 \\
\hline Machinery, equipment and &
\end{tabular}

Source: calculated on data released by the Federal Customs Service (FCS).

In January-April 2015, Russian exports and imports turnover shrank against the same period 2014 practically with all trade partners minus Cuba. Supplies of

1 An in-depth analysis of major foreign trade indices given in chapter 3, OMES No. 10, 2015. 
Russian goods to Cuba increased by $15.5 \%$, Cuba supplied goods to Russia threefold more.

Table 3

\section{TYPES OF RESTRICTIVE MEASURES APPLIED BY THIRD COUNTRIES}

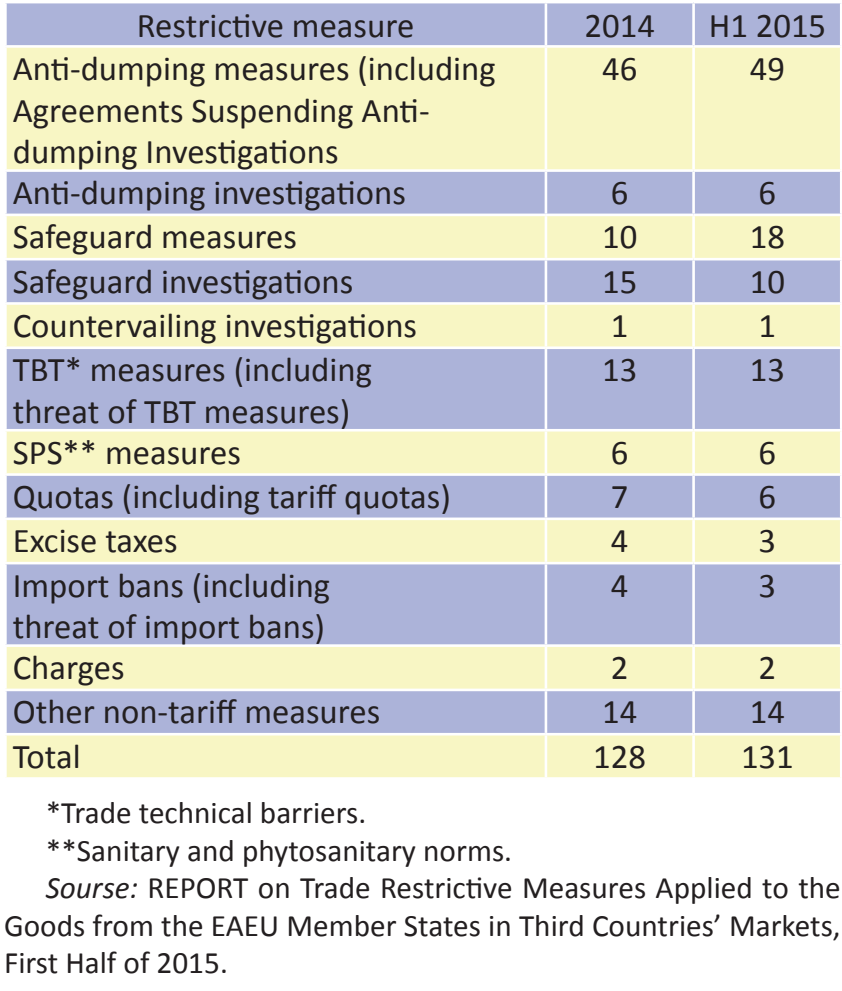

Russian merchandise turnover with $\mathrm{CIS}$ member states continues falling. Russian export to these countries fell by $35.4 \%$ for the first four months 2015 , and Russian imports down by $45.8 \%$. The share of CIS in Russian foreign trade turnover contracted from $13.1 \%$ in January-April 2014 to 11.8\% in January-April 2015.

Russian merchandise trade with EAEU member states also fell: for the first four months 2015 constituting $\$ 12.7 \mathrm{bn}$ down $27.5 \%$ against the same period 2014.
In May 2015, Eurasian Economic Commission released a report on the restrictive measures applied to goods from the EAEU member-states ${ }^{1}$. Monitoring conducted by the Eurasian Economic Commission in the first half of 2015 has showed the application of 131 measures having or which may have a negative impact on the access of goods from the EAEU Member States to third countries' markets. $42 \%$ (55 measures) are anti-dumping measures, $21 \%$ ( 28 measures) fall to special safeguard measures; and one countervailing investigation is being conducted now.

Ninety five measures, this being $73 \%$ of all restrictive measures identified, fall to trade barriers that have a negative impact on the EAEU foreign trade operators. These include anti-dumping measures and safeguard measures, bans and restrictions related to SPS and TBT measures, discriminatory excise taxes and charges, quantitative restrictions, as well as administrative measures limiting the access to third countries' markets.

Out of all existing technical barriers, one can point out the bans on trade in and use of asbestos-containing materials in the EU and Iran, the EU REACH chemicals policy, the EU classification of nickel compounds as potentially hazardous and corresponding tougher regulations governing trade in such compound.

SPS measures having the effect of barriers to trade were identified in the EU, Ukrainian and Chinese markets. Measures of this kind apply to meat, animal products, grain and fodders, which originate from the Russian Federation.

The highest number of restrictions apply EU (22 measures), Ukraine (21), India (13), Turkey (12), the USA (9) and Uzbekistan (7).

1 http://www.eurasiancommission.org/ru/act/trade/dotp/ Pages/dostup.aspx 